Abstracta Iranica Abstracta Iranica

Revue bibliographique pour le domaine irano-aryen

Volume 26 | 2005

Comptes rendus des publications de 2003

Dìdār-hā-yi dūr. Pažūheš̄ dar adabiyāt-i safar-nāma-ī

hamrāh bā kitāb-šināsīi safar-nāma-hā-yi fārsī.

Tehrān, Čāpār, 1381, 187 p. [Visites lointaines.

Étude sur la littérature de voyage avec une

bibliographie des récits de voyage en persan]

Ève Feuillebois-Piérunek

C OpenEdition

Édition électronique

URL : http://journals.openedition.org/abstractairanica/1776

ISSN : 1961-960X

Éditeur :

CNRS (UMR 7528 Mondes iraniens et indiens), Éditions de l'IFRI

Édition imprimée

Date de publication : 15 mai 2005

ISSN : 0240-8910

Référence électronique

Ève Feuillebois-Piérunek, « Dīdār-hā-yi dūr. Pažūhešī dar adabiyāt-i safar-nāma-ī hamrāh bā kitāb-šināsīi safar-nāma-hā-yi fārsī. Tehrān, Čāpār, 1381, 187 p. [Visites lointaines. Étude sur la littérature de voyage avec une bibliographie des récits de voyage en persan] », Abstracta Iranica [En ligne], Volume 26 | 2005, document 337, mis en ligne le 07 décembre 2005, consulté le 25 septembre 2020. URL : http://

journals.openedition.org/abstractairanica/1776

Ce document a été généré automatiquement le 25 septembre 2020.

Tous droits réservés 


\title{
Dìdār-hā-yi dūr. Pažūhešì dar adabiyāt- i safar-nāma-ī hamrāh bā kitāb-šināsī-i safar-nāma-hā-yi fārsī. Tehrān, Čāpār, 1381, 187 p. [Visites lointaines. Étude sur la littérature de voyage avec une bibliographie des récits de voyage en persan]
}

\author{
Ève Feuillebois-Piérunek
}

1 L'ouvrage se veut une source pour les sciences humaines (histoire, ethnologie, sociologie et littérature essentiellement). L'introduction brosse à grands traits une brève et assez schématique histoire de la composition de ce type de récits. Du $9^{\mathrm{e}}$ au $12^{\mathrm{e}}$ s., les relations de voyage sont plutôt le fait de marchands ou de pèlerins (Abū Ishạâ Istavrī, Sulaymān Tājir, Nāṣir Hुusraw, Abū al-Ašraf Ḥusaynī). Les périodes mongole, timouride et safavide ne comptent qu'un nombre modeste de ces ouvrages au regard de la période concernée (une douzaine d'écrits en cinq siècles). Par contre, la période qajare connaît une véritable explosion : plus de 200 écrits consacrés à l'Inde, aux lieux saints de la Mekke et Médine, mais aussi et surtout à l'Europe. Ils sont le fait de «touristes» ou d'ambassadeurs, et expriment l'étonnement des Persans devant les rapports sociaux et les nouveautés technologiques observés.

2 Ensuite vient une typologie des récits de voyage : voyages réels ou imaginaires, voyages d'affaires, d'étude ou de distraction, missions politiques, culturelles ou militaires, pèlerinages, récits critiques ou ironiques, récits en vers ou en prose. De nombreuses et longues citations de journaux de voyage forment une sorte d'anthologie illustrant les différents genres, mais aucune véritable analyse n'est fournie. Un chapitre est consacré aux écrits des femmes. L'ouvrage se termine par une imposante liste de récits de 
voyage en manuscrits ou imprimés. Peut aider à débuter une recherche sur ce type de littérature, surtout par son aspect bibliographique.

INDEX

Thèmes : 11.1.0. Généralités

Mots-clés : récits de voyage, littérature de voyage, Travel Literature

nompropre Timourides, Safavides, Qajars, Nāṣir Huusraw, Naser Khosrow

\section{AUTEURS}

\section{ÈVE FEUILLEBOIS-PIÉRUNEK}

Sorbonne Nouvelle - Paris III 